\title{
THE VLACHS - SEVERAL RESEARCH PROBLEMS
}

\author{
ILONA CZAMAŃSKA
}

\begin{abstract}
The purpose of this article is to show the inconsistency of terminology, conceptual and substantive research on Vlachs, carried out on different areas of their residence. Seeing the need to clarify the terminology, the author proposes the use of names: "Wallachia", "Wallachians" only in the sense of the state, in relation to the principalities of Wallachia and its people, and "Vlachia", "Vlachs" only in the sense of ethno-society or social group. Particular attention was paid to the traps that you will encounter, examining various aspects of the life and activities of the Vlachs. The similarities on the Vlachian Right in contact with different regional conditions led to the formation of a completely new quality ethnic, legal and cultural factors that should be taken consider about conducting research. Only advanced international cooperation and joint research initiatives can yield significant progress in research about Vlachs.
\end{abstract}

Ilona Czamańska, professor, Adam Mickiewicz University, Institute of history, ul. Św. Marcin 78, 61-809 Poznań, Poland, e-mail: czaman@amu.edu.pl

Keywords: Vlachs scientific terminology, Vlachian Right, research problems about Vlahs, Military Borderlands in the Balkans.

DOI: http://dx.doi.org/10.14746/bp.2015.22.1

Research into the history of the Vlachs has recently become quite popular in various countries of Central and South East Europe, however, most often it has been conducted within some defined geographical, political or linguistic, etc., area. The entirety of the issue is extremely difficult to investigate in a comprehensive research framework because of the vast geographical territory it pertains to, as well as due to the lack of unanimous terminological and conceptual consistency present both in the historical sources and in the contemporary research literature. For this reason it is essential to undertake far reaching collaboration in order to make the terminology more precise and mark out joint research directions.

The first task, namely making the object of research more precise, is by no means easy. The term Vlachs or Wallachians has been used to refer to:

1. People speaking Eastern Romance languages or dialects

2. People living according to a particular lifestyle, mostly dealing with mountain pastoralism (sometimes specific features of the pastoral economy are mentioned, for example cheese-making)

3. People who in their historical past had a defined social status (the Vlachian/ Wallachian Right - Ius Valachicum)

4. People who in the Middle Ages established Romanian principalities

However, all the above criteria, taken altogether as well as one by one will prove to be very imprecise and completely irrelevant to today's situation even if the fourth category, that is contemporary Romanians are excluded. Seeing the need for clari- 
fication in this regard, I propose that the scientific work consistently use the name "Wallachia", "Wallachians" only in the sense of the state, in relation to the principalities of Wallachia and its people, and "Vlachia", "Vlachs" only in the sense of ethnicsociety or social ${ }^{1}$.

From the above list of criteria, the language seems to be the most straightforward, although even here numerous problems and traps are awaiting the researcher. The first and the most serious problem is the fact that the Vlachs continuously lived together with other ethnic groups, what in some areas very quickly led to linguistic assimilation. The language became assimilated the fastest in Slavonic countries, especially the Eastern Orthodox as the Slavonic religious rituals became an additional binding factor.

According to Paisiy Hilendarski the religion was apparently enforced on the Vlachs by the Bulgarian rulers (it was said that Tsar Asen ordered to cut off a tongue from everyone who would not pray in Slavonic ${ }^{2}$ ), although the Vlachs themselves described the language used in the Orthodox Church as Serbian. Undoubtedly, the territorial range occupied by the Vlachs whose religion was Orthodox was much wider than the area occupied by the Bulgarian countries in the Middle Ages. On the other hand, according to the oldest historical records the Vlachs who lived in Dalmatia, Panon Croatia and Slovenia were perceived as Roman Catholics, which however did not have a negative impact on the speed of the process of Slavisation.

The assimilation process is itself sometimes quite complicated, which is visible in the case of Kobylnica Wołoska, the village in Eastern Poland that I have investigated. The village was founded in the $16^{\text {th }}$ century by the ethnic Vlachs. When the parish register book was found under a rotten roof of the Orthodox Church which dated back to the $17^{\text {th }}$ century, it turned out that the church must have temporarily been a Unite church as well, as some entries were made in Latin, possibly by Roman Catholic priests $^{3}$.

However in the $19^{\text {th }}$ century the church was taken over by Ukrainian clergymen and the ensuing Ukrainisation of the local community is well preserved in the historical cemetery dating back to the $18^{\text {th }}$ century. This situation changed in the $20^{\text {th }}$ century after the rebirth of the Polish state when gradually a Polish identity, Polish language and ... Catholicism started to dominate. The traces of the Vlachian origin are, nevertheless still preserved in the names of the inhabitants, which interestingly in the majority have not changed since the $17^{\text {th }}$ century.

Slavisation processes occurred much earlier also in other regions. An interesting historical material for this issue is available in a set of legal acts concerning trade rela-

\footnotetext{
${ }^{1}$ Such a distinction would do well to enter in all languages, for the Polish language would suggest "Wołoch" and "Włach". Vlachs name cannot be used as a substitute for the name Aromanians, which refers to only one group of Vlachs.

${ }^{2}$ Paisij Chilendarski, Stowianobułgarska historia, przełożył Franciszek Korwin Szymanowski, „Czytelnik”, Warszawa 1981, p. 30.

${ }^{3}$ The register book because of the dispute concerning its ownership was deposited in the State Archives in Przemyśl in 2012.
} 
tions between Dubrovnik and the neighbouring Turkish territories in the $16^{\text {th }}$ and $17^{\text {th }}$ centuries ${ }^{4}$. Two large volumes of several hundred pages mostly refer to trading with the Vlachian voivodes from the area of Bosnia, Herzegovina and Montenegro. One of the family names which occured quite often in the documents is the Petrovic family from the area of Nikšić where the names of the family members were Slavonic, and more precisely Serbian: Jovan, Pavao, Vukašin, Milutin, Vuk, and others. Next to these there is also the Vlachian Brat (Prat). In another family the name Omer appears which most likely shows that the family was Islamised. Although the names can provide a clue they, however do not reflect the language that the family clans were using on an everyday basis.

In turn, in the southern parts of the Balkan Peninsula the Hellenization processes were taking place. It needs to be remembered though that from the Greek perspective these processes are perceived in the opposite order and viewed as the Romanisation of the Greek people and not as the Hellenization of the Romance people. This issue is also connected with the debate concerning the origins of the Vlachs - another huge problem that I shall return to. In effect the bilingualism and often also multilingualism of the Vlachian community who lived in Greece, Macedonia or Albania not only makes a univocal classification difficult but also causes semantic misunderstandings. For example, the Hellenic Vlachs were often referred to as 'Cincari'. For some contemporary Serbians this is synonymous to the term Vlach, while for Bulgarians or Macedonians the term refers exclusively to urban communities with a very high social status more readily identified with the Greeks than the Vlachs. Still in a different way in the traditional Serbian historiography the name Cincari was used to mean the Vlachs who lived in Serbian towns and cities and who dealt with trading, irrespective of the language they used or their social status ${ }^{5}$.

Although the discussion of linguistic research problems is best left to philologists, if I may, I would like to draw attention to one aspect connected with historical changes. There are very scant records dating back further than the $20^{\text {th }}$ century concerning the language used by the Vlachs from areas outside today's Romania. The source of research problems is not only caused by the cultural and linguistic symbiosis with other ethnic groups. In some Vlachian communities we can observe the development of a Romanian identity together with learning the Romanian language and using it for everyday communication. Such phenomenon is present, for example in Macedonia and in Vojvodina.

A relevant parameter which allows to distinguish the Vlachs is the cultural factor - nomadic or half-nomadic mountain pastoralism, shepherd's hut economy and rennet cheese making either in sheep skin or in a sheep's stomach. Understandably, this factor should be perceived mainly from the historical perspective as today it is re-

\footnotetext{
${ }^{4}$ State Archives in Dubrovnik, F. 31, 41/A1-A2.

5 Д. Й. Поповић, О Цинцарима. Пролози питању постанка намег грађанског друштва, Београд 2008; N. Trifon, Cincari narod koji nastaje, Beograd, 2010; Pribislav B. Marinković, Cincarskosrpski rečnik, Beograd, 2009.
} 
tained in relic form with a tendency towards complete demise in some regions. These changes result from civilizational and economic transformations as well as from the changes in natural conditions as a result of the predatory economy in the past.

The pastoral culture of the Vlachs, despite its seeming primitivism, was a result of centuries-long practice combined with excellent knowledge of the mountains. Their culture shows many convergent themes with analogous cultures of the Caucasus and even of Central Asia. It would be also interesting to investigate these analogies with the traditions of highlanders from Western Europe. For example, Zef Mirdita - a distinguished researcher of the Western Balkan Vlachs noted numerous convergences between the Vlachian culture and the culture of highlanders from Sardinia ${ }^{6}$. The gradual assimilation of the Vlachian culture by other ethnic groups must have been a result of a long-term process of symbiosis. In practice, the natural conditions, especially in the majority of the Balkan Peninsula enforced such a symbiosis. In effect, the culture of the Vlachs spread over the entire Balkans, while showing many common features concerning the major issues, in details it represents quite a variety.

Ascribing the exclusively pastoral occupation to the Vlachs is also not entirely consistent with the reality. Historical records from the Middle Ages do not allow for an unequivocal distinction between the Vlachian people and the Romance people, e.g., people who remained after the Roman times and inhabited urban areas, or were settled throughout the medieval times, especially in coastal regions. Such a lack of certainty occurs with reference to a well-known text written by Konstantin Porfirogenet which includes the information regarded as the first mention of the Vlachian people; namely, Konstantin Porfirogenet wrote about people who used the Latin language and lived in Tesalia, who according to him came from Italy and were settled in Tesalia during the Diocletian reign 7 . Porfirogenet does not mention the exclusively pastoral lifestyle of these people and the later term "Kućovlasi" might indicate that the Vlachs who inhabited the Macedonian-Greek borderland (in the present estimation) lived in permanent houses (Serbian kuća - house). On the other hand, one hundred years later Anna Comnena in her writings identifies the Vlachs as ancient Myzians who were essentially nomads. Her description, however refers to the territory belonging to Bulgaria ${ }^{8}$. In later records from the $12^{\text {th }}, 13^{\text {th }}$, and $14^{\text {th }}$ centuries the Vlachs are mainly referred to as a pastoral people speaking the Romance language ${ }^{9}$. Yet, the emergence of the various

\footnotetext{
${ }^{6}$ Zef Mirdita, Vlasi starobalkanski narod, Zagreb, 2009, p. 103.

${ }^{7}$ Constantinus Porphyrogrnitus, De thematibus et administrando imperio, Bonn 1840, p. 125 i n.

${ }^{8}$ Anna Komnena, Aleksjada, t. 1, Wrocław - Warszawa - Kraków, 1967, p. 131; t. 2, Wrocław Warszawa-Kraków 1972, p. 34, 73-74.

${ }^{9}$ Simon de Kéza, Gesta Hunnorum et Hungarorum, wyd. G. Popa-Lisseanu, Bucureşti, 1935, p. 32; toż w: Scriptores Rerum Hungaricarum, t. I, wyd. E. Szentpétery, Budapestini, 1937, p. 156-157; Anonymi Bellae Regis notarii Historia Hungarica de septem primis ducibus Hungariae, in: J. Schwandtner, Scriptores Rerum Hungaricarum, t. 1, Vindobonae 1746, p. 10; Anonymus Bele regis notarius, Gesta Hungarorum, wyd. G. Popa-Lisseanu, Bucureşti 1934, p. 32 and in: Scriptores Rerum Hungaricarum, t. I, ed. E. Szentpétery, Budapestini 1937, p. 45; Anonymi Descriptio Europae Orientalis, ed. O. Górka, Cracoviae 1916, p. 13-14.
} 
Vlachias in the early $13^{\text {th }}$ century as territorial names clearly points to at least a halfsettled lifestyle ${ }^{10}$.

In the $14^{\text {th }}$ century this lifestyle undoubtedly became a fact on most lands in Central Europe and in the Balkans. The Vlachian settlement is related to the "Vlachian Right" considered as a unique phenomenon and a mystery. It appeared most likely as a result of the gradual disintegration of the clan structures and the colonization processes. Initially the mountain regions belonged to the king and ruler and they functioned as servitudes. However, even the ownership of the highland areas started to be passed on to private owners which enforced a more precise definition of the rights and responsibilities of the Vlachian people towards individual land owners and the king. At the time in Orthodox countries many monasteries became established in the mountains and obtained properties in which the Vlachs lived or worked. The development of the state and fiscal structure which followed together with the emergence of private ownership required to keep a more precise register of people who had to be ascribed to a particular place. The first documents connected with settlement on the Vlachian Right started to appear in the $14^{\text {th }}$ century. Since we do not know any earlier records concerning the Vlachian Right, we do not have solid information about its origin. Nevertheless, we know that the Vlachian Right occurred in all of the territories inhabited by the Vlachs almost at the same time and it included the same core elements although there were some differences in details. The characteristic features of the Vlachian Right common for the whole area where it occurred included:

1. the right to travel and carry weapons (sometimes including the right to hunt),

2. lack of labour service to the land owner or its minimum rate; levies paid in kind (part of livestock) or in money,

3. military service obligation towards the country (various forms depending on the country $)^{11}$.

Beyond doubt, the first two clauses of the right were closely connected with the lifestyle and pastoral economy of the Vlachian shepherds since the very beginning, however clause three, that is the obligation of military service seems especially interesting. In ancient times no matter where the Vlachs lived they must have occupied the

${ }^{10}$ Geoffroy de Villehardouin, La conquête de Constantinople, éditée et traduite par Edmond Faral, t. I, II, Paris 1961; Geoffroy de Villehardouin, Zdobycie Konstantynopola, ed. Zdzisław Pentek, Poznań 2003, no 202, 311, 352, 354, 359, 363, 371, 389, 394, 404, 406, 407, 410, 412, 451, 459, 472; Robert de Clari, Zdobycie Konstantynopola, ed. Zdzisław Pentek, Poznan 1997, no LXIV, CXII. The latter chronicler describes Vlachia, as a land covered mountains, to which you can not get otherwise, except through a gorge (p. 61). Undoubtedly, so there could be a case of Wallachian Plain, because the road to it, going from Constantinople, lead through the mountains, but by the Danube. This was probably the territory located on the territory of Bulgaria or Macedonia. In the documents of that time, Kaloian is called the Tsar Bulgarians and Vlachs or Bulgaria and Vlachia, also jurisdiction of the Archbishop Tarnovo extended on "the whole of Bulgaria and Vlachia" - see: Correspondence Tsar Kaloian and Archbishop Vasily with Pope Innocent III in the years 1202-1204 - Иванъ Дуйчевъ, Изъ старата българска книжнина, "Хемус" София 1944, p. 1-24.

${ }^{11}$ Grzegorz Jawor, Osady prawa wołoskiego i ich mieszkańcy na Rusi Czerwonej w późnym średniowieczu, Lublin, 2004, p. 59-77; Zef Mirdita, Vlasi starobalkanski narod, passim. 
territory belonging to the Roman Empire. Some time ago, at my request, Poznań researchers in antiquity and Byzantium investigated historical records in search of any traces of the social category of shepherds who were obliged to do military or border guard service in ancient Rome. The investigation did not discover any such records. It is well known from other sources that the Romans did not know at all how to use mountains as a defensive element, with the evacuation of Dacia as a Roman province being the best example.

Prior to that, as recent research has shown, the Byzantines did not have a defence system in the mountains at the time when the first Bulgarian state was being created that is in the second half of the $7^{\text {th }}$ century. This made it easy for Bulgarians to cross the border and penetrate the centre of the Byzantine state. Apparently, it was the Bulgarians who first introduced a permanent border guard by shepherds in the Haemus Mountains ${ }^{12}$. It is very likely that the shepherds were Vlachs. In the $11^{\text {th }}$ century using Vlachian shepherds to guard borders was in the Byzantium common practice, to be used later in all the states where the Vlachs had settled.

The Vlachian Right became the foundations for the development of settlements in the mountains, and not only of the Vlachs but also people of different ethnic origins. Thanks to the personal freedom, the right to carry weapons and the privileges which stemmed from their obligation of military service the right assured a privileged position for the Vlachian clans in comparison to other categories of peasants. In some countries (e.g. in Hungary) the duty to guard borders was connected with the obligation to build and defend strongholds. The growing importance of obligatory military service led to the use of the Vlachian Right in typical military settlements not only of the ethnic Vlachs and not only in the mountains. According to a document issued in 1436 by a Croatian ban Ivan Frangepan for the Vlachs under his rule, those who lived from sheep farming (had a flock) should serve by paying levies and taxes and those who did not were obliged to serve in person with the shield and sword ${ }^{13}$. The Vlachs on Croatian soil retained their status despite the fact that they fairly quickly lost their native language and the land they inhabited belonged to private owners.

The system of military settlement was used by the Hungarians since early times; however the emergence of the strong Ottoman Empire intensified this long-in-use practice. Additionally, the demographic factor was also important, namely the reoccurring exodus of people from the area conquered by the Islamic invader driving people out of the land in smaller or larger numbers. In the $15^{\text {th }}$ century the area of intensive military settlement included the following regions (banates) in the majority inhabited by the ethnic Vlachs: Jajce, Šabac and Srebrenik.

In the $16^{\text {th }}$ century these regions were under Ottoman rule which continued the military settlement in the area and in other Balkan regions using the Vlachian Right.

12 Kirył Marinow, „Góry Hemos jako miejsce schronienia, baza wojskowa i punkt obserwacyjny w świetle bułgarsko-bizantyńskich zmagań zbrojnych okresu wczesnego średniowiecza (The Haemus Mountains as a shelter, an attack outpost and an observation post $i$ the lightof the Bulgarian-Bizantine military relations in the Elary Middle Ages)", Balcanica Posnaniensia. Acta et studia, t. 21, 2013, p. 5-18.

${ }^{13}$ Zef Mirdita, Vlasi starobalkanski narod, p.130. 
In effect the Vlachs (not necessarily the ethic ones) formed many military categories in the Ottoman Empire such as: martolos, also called in Greek armatols, vojnuc, dervenc or kirac. On the other side of the border, in Christian countries the Vlachs were used in the same way to guard the borders and to organize the Military Borderline. In view of the huge territorial losses suffered by the Kingdom of Hungary in the $16^{\text {th }}$ century, in the $17^{\text {th }}$ century an intensive colonization of the borderland regions of Slavonia was undertaken. The Vlachs were the most wanted colonists and it is for them that in 1630 Emperor Ferdinand II issued a special statute ${ }^{14}$. The Vlachian settlers retained their traditional social structure in the form of Knezes and Voivodes, but for military reasons five major outposts were established between the river Sava and Drava: Križevci, Koprivnica, Ivanić, Varaždin and Zagreb. All of them were subject generalat of Varaždin. Most of Vlachs lived in kapetanat's Križevci, Koprivnica and Ivanić $^{15}$. Those Vlachian settlers who served in the army were exempt from paying levies and taxes and received soldier's pay. However, all the settlers were obliged to keep border guard day and night. When in 1699 and 1718 the lands taken over by the Turks returned to their homeland of Croatia and Hungary, they in the vast majority became the Military Borderland area, which then stretched from Lika to the Banate of Severin. The latter region was especially popular among the Vlachian settlers. Indeed, the Vlachian Right was used throughout the entire region of the Military Borderland to settle various ethnic groups including Serbs, Croats, Albanians and others: all of them were also called Vlachs ${ }^{16}$.

In the $18^{\text {th }}$ century the Walalchian Right also became the point of reference for military settlement in the generally lowland region of Vojvodina. The Vlachs who settled there were mainly Serbs although there were also Romanians and in the urban areas the Greek-Vlachian Cincari. A peculiarity connected with the Vlachian settlers from Vojvodina was not their highland or pastoral specialization but the fact that their work was on the river. In the areas located further to the north, on the Polish-HungarianRussian borderland other ethnic groups were as settled on the Vlachian Right. In these regions the Vlachian Right was used primarily in the areas where a pastoral economy prevailed, but also, as reported in the research conducted by Grzegorz Jawor, in those places where the natural conditions were exceptionally difficult ${ }^{17}$. What is more, in some regions the Vlachian Right evolved or was lost, as in the example of, the already mentioned, Kobylnica Wołoska.

In view of the above, even with reference to the settlement right and social status the situation is very unclear. As a matter of fact, every region requires a special approach for research purposes.

14 Zef Mirdita, Vlasi starobalkanski narod, p. 143-154.

${ }^{15}$ Hrvoje Petrić, Pogranična društva i okoliš. Varaždinski generalat i Križevacka županija u 17. stoljeću, Samobor-Zagreb, 2012, p. 108-114.

${ }^{16}$ Drago Roksandić, Triplex confinium ili o granicama i regijama hrvatske povjesti. 1500-1800, Zagreb, 2003.

${ }^{17}$ Grzegorz Jawor, Osady prawa woloskiego i ich mieszkańcy, p. 124-125. 
The problem of ethno genesis and Vlachian migration is even more complicated. In historical records, the Vlachs appear relatively late $\left(10^{\text {th }}\right.$ century) and the oldest sources give rise to many possible interpretations. Unfortunately, for several recent centuries the investigation of the Vlachian ethno genesis was so much dominated by political issues that any progress in this respect was incredibly difficult. Independently from all questions, doubts, inconsistencies which remain, one thing seems certain. These communities were nomadic, migrating all the time and not permanently settled in one place. An attempt to establish the route of Vlachian migration could prove to be the key to solving the problem of ethno genesis, if it was not for the fact that these migrations could and probably did occur in many directions at the same time. Apart from that, they spread not only over the Balkans and the Carpathians, but probably also over the Caucasus, the Adriatic islands and possibly over the entire region of the Mediterranean Sea. It needs to be clearly admitted that our knowledge concerning the ethno genesis and the primary migrations of the Vlachs is more than modest.

The list of problems which remain to be investigated could be further extended. The social, propriety and economic transformations have mostly led to the demise of the pastoral lifestyle of the Vlachian shepherds. The changes in the state borderlines in the Balkans and in Central Europe in the $19^{\text {th }}$ and $20^{\text {th }}$ centuries have rendered most of the military borderlands completely useless. The introduction of new principles of social structure and modern defensive systems has entirely relegated the traditional social and legal system. The Vlachs have blended into modern nations and communities. In a completely natural way, their traditional culture, language and customs gradually give way to the way of life corresponding to modern times. On the other hand, we can observe more and more often instances of a conscious return to the roots: the language, customs and pastoralism. More and more researchers from different disciplines have become interested in the Vlachian people and they are investigating their language, culture and also their place in the contemporary world. In Southern and Eastern Europe the traces of Vlachian traditions are visible literally everywhere and its diversity and multidimensionality is enormous. In order to understand it and keep the entire problem under control we need the involvement of many researchers. It is also essential to exchange our knowledge and to take joint research initiatives as only such collaborative efforts can bring significant progress in research concerning one of the most interesting ethnic and cultural groups in Europe.

\section{SELECTED BIBLIOGRAPHY}

Anna Komnena, Aleksjada, t. 1, Wrocław - Warszawa - Kraków 1967, p. 131; t. 2, Wrocław - Warszawa Kraków 1972, p. 34, 73-74.

Anonymi Bellae Regis notarii Historia Hungarica de septem primis ducibus Hungariae, w: J. Schwandtner, Scriptores Rerum Hungaricarum, t. 1, Vindobonae 1746, p. 10;

Anonymi Descriptio Europae Orientalis, ed. O. Górka, Cracoviae 1916, p. 13-14.

Anonymus Bele regis notarius, Gesta Hungarorum, wyd. G. Popa-Lisseanu, București 1934, p. 32; 
Armbruster Adolf, Romanitatea românilor, istoria unei idei, Bucuresti 1972.

Aromânii. Istorie, limba, destin, coord. Neagu Djuvara, Bucureşti 1996.

Barszczewska Agnieszka, Mołdawscy Csángó a Rusini Karpaccy (1867-1947). Problemy rozwoju tożsamości zbiorowej w Europie Środkowo-Wschodniej w XIX i XX wieku, Warszawa 2012.

Borowski Stanisław, Materjaty do ćwiczeń seminaryjnych z historji prawodastw stowiańskich, I: Statuty cara Stefana Duszana z lat 1349 i 1354, Warszawa 1934.

Chaloupecký Václav, Valaši na Slovensku, v Praze 1947.

Constantinus Porphyrogenitus, De thematibus et administrando imperio, Bonn 1840.

Constantinus Porphyrogrnitus, De thematibus et administrando imperio, Bonn 1840, p. 125 i n.

Czamańska Ilona, Problem pochodzenia Wolochów, w: Wędrówka i etnogeneza w starożytności i w średniowieczu, red. M. Salamon, J. Strzelczyk, Kraków 2004, p. 327-336.

Czamańska Ilona, Wolosi w Europie, w: Wołoskie dziedzictwo w Karpatach, Istebna 2007.

Czamańska Ilona, Этнические и политические граниы румынов, w: Гранични и етнонационални конфликти в Средна и Югоизточна Европа, София 2008.

Dobrowolski Kazimierz, Migracje wołoskie na ziemiach polskich, Lwów 1930.

Drago Roksandić, Triplex confinium ili o granicama i regijama hrvatske povjesti. 1500-1800, Zagreb 2003.

Geoffroy de Villehardouin, La conquête de Constantinople, éditée et traduite par Edmond Faral, t. I, II, Paris 1961;

Geoffroy de Villehardouin, Zdobycie Konstantynopola, ed. Zdzisław Pentek, Poznań 2003.

Georgius Cedrenus, Joannus Skylitzes opere, II, Bonnae 1839.

Hrvoje Petrić, Pogranična društva i okoliš. Varaždinski generalat i Križevacka županija u 17. stoljeću, Samobor - Zagreb 2012.

Jawor Grzegorz, Osady prawa wołoskiego i ich mieszkańcy na Rusi Czerwonej w późnym średniowieczu, wyd. II, Lublin 2004.

Kossakowski Stanisław Kazimierz, Monografie historyczno-genealogiczne niektórych rodzin polskich, t. III, Warszawa 1872.

Luković Miloš, Transhumantni migrace pastevců v centrálních a západnich oblastech Balkánu, [in:] Tradíčni agrárni kultura v kontextu společenského vývoje středni Evropy a Balkánu, Eds. Z. Kłodnicki, M. Luković, P. Slarkovský, R. Stoličná, M. Válk, ,”Etnologické Studie”, Brno, 2012, 12, 147-196.

Marinković Pribislav B., Cincarsko-srpski rečnik, Beograd 2009.

Marinow Kirył, „Góry Hemos jako miejsce schronienia, baza wojskowa i punkt obserwacyjny w świetle bułgarsko-bizantyńskich zmagań zbrojnych okresu wczesnego średniowiecza (The Haemus Mountains as a shelter, an attack outpost and an observation post $i$ the lightof the Bulgarian-Bizantine military relations in the Elary Middle Ages)", Balcanica Posnaniensia. Acta et studia, t. 21, 2013, p. 5-18.

Mirdita Zef, Vlasi starobalkanski narod (od povijesne Mojave do danas), Zagreb 2009.

Paisij Chilendarski, Stowianobułgarska historia, przełożył Franciszek Korwin Szymanowski, „Czytelnik”, Warszawa 1981, p. 30.

Papacostea Şerban, Between the Crusade and the Mongol Empire, Cluj-Napoca 1998.

Pol Wincenty, Rzut oka na pótnocne stoki Karpat, Kraków 1851.

Powieść minionych lat, ed. F. Sielicki, Wrocław - Warszawa - Kraków 1999.

Przywilej lokacyjny miasta Tarlowiec z 1557 roku na obszarze Kobylnicy Ruskiej i Kobylnicy Wołoskiej, opr. Stanisław Baran, Ewa Gryń-Piszczek, Przemyśl 2007.

Robert de Clari, Zdobycie Konstantynopola, ed. Zdzisław Pentek, Poznań 1997

Scriptores Rerum Hungaricarum, t. I, wyd. E. Szentpétery, Budapestini 1937.

Simon de Kéza, Gesta Hunnorum et Hungarorum, wyd. G. Popa-Lisseanu, Bucureşti 1935, p. 32; toż w: Scriptores Rerum Hungaricarum, t. I, wyd. E. Szentpétery, Budapestini 1937, p. 156-157;

Stadnicki Aleksander, $O$ wsiach tak zwanych wołoskich na pótnocnym stoku Karpat, Lwów 1848.

Sučević Branko P., Razvitak „vlaških prava” u Varaždinskom generalatu, „Historijski zbornik”, br. 1-4, Zagreb 1953. 
The Lemkos of Poland. Articles and Essays, ed. Paul Best, Jarosław Maklak, Kraków-New Haven 2000. toż w: Scriptores Rerum Hungaricarum, t. I, wyd. E. Szentpétery, Budapestini 1937, p. 45;

Trifon N., Cincari narod koji nastaje, Beograd 2010;

Woloskie dziedzictwo Karpat, red. Jan Szymik i Leszek Richter, Czeski Cieszyn 2008.

Zef Mirdita, Vlasi starobalkanski narod, Zagreb, 2009, p. 103.

Бојанић Д., Власи у северной Србији и нихови први кануни, Историјски Часопис, т. XVIII, 1971, p. 225-269.

Даскалов Георги, Армъните в Гъпиия. История на един непризнат народ, София 2005.

Дуйчевъ Иванъ, Изъ старата българска книжнина, «Хемус» София 1944, p. 1-24.

Зборник Константина Јиречека, I, Београд 1959; II, Београд 1962.

Здравева Милка, Тодоровски Глигор, Номадското сточарство во Македонија од ХIX век до 1918, Скопје 1997.

Карахасан-Чънар Ибрахим, Етническите малиинства в България, София 2005.

Матковски Александар, Номадското сточарство во Македонија од XIV до ХIX век, Скопје 1996.

Поповић Д. Й., О Циниарима. Пролози питању постанка намег грађанског друштва, Београд 2008; 